\title{
Analysis of the Influence of Managerial Ownership, Audit Quality and Audit Committee on Income Management (Study on Manufacturing Companies in the Consumer Goods Sector Listed on the Indonesia Stock Exchange 2014-2018)
}

\author{
Sri Ningsih Sitanggang ${ }^{1}$, Arfan Ikhsan ${ }^{2}$, Nasirwan ${ }^{3}$ \\ ${ }^{1}$ Master Student of Accounting Department, Universitas Negeri Medan, Indonesia \\ ${ }^{2,3}$ Universitas Negeri Medan, Indonesia \\ sriningsihsitanggang@gmail.com
}

\begin{abstract}
This study aims to examine the effect of managerial ownership, audit quality and audit committee on earnings management. The research was conducted at manufacturing companies in the consumer goods sector which were listed on the Indonesia Stock Exchange in 2014-2018. The sampling technique used purposive sampling technique and obtained 10 companies that became samples. Hypothesis testing is done by using multiple regression analysis. The results of this study indicate that: first, managerial ownership does not have a significant effect on earnings management. It can be seen that the t-count is smaller than the $t$ table $(0.152<1.678)$ with a significance value of $0.880>0.05$. Second, audit quality affects earnings management. It can be seen that the $t$-count is greater than the $t$-table (2.274> 1.678), with a significance value of $0.028<0.05$. Third, the audit committee has a significant effect on earnings management. It can be seen that the $t$-count is greater than the t-table $(2.894>1.678)$, with a significance value of $0.006<0.05$. If reviewed together, the three variables of managerial ownership, audit quality, and audit committee have an effect of $25.4 \%$ on earnings management.
\end{abstract}

\section{Keywords}

managerial ownership; audit quality; audit committee; earnings

\section{Introduction}

Every company always tries to maximize the benefits it gets. Various strategies are applied to achieve these goals. The company will always keep its performance looking good in the eyes of its stakeholders. But in reality, companies are often faced with various obstacles that can cause a decline in performance and even financial difficulties and eventually go bankrupt. And of course the company will try to cover up this unhealthy condition from its stakeholders. One of them is by way of earning management (Utami, 2017).

Earnings management is interference in the process of preparing external financial reporting, with the aim of obtaining personal benefits (Almadara, 2017). According to Scott (2014: 403) earnings management is a choice made by managers in determining accounting policies to influence reports to achieve certain goals. Earnings management can reduce the credibility of financial reports when used for decision making, because earning management is a form of manipulation of financial reports that is the target of communication between managers and external parties of the company (Utami, 2017).

The agency relationship between shareholders and managers is described in agency theory. Agency theory is a theory that explains that agency relationships arise when one or 
more people (principal) employ another person (agent) to provide a service and then delegate decision-making authority to the agent (Almadara, 2017). The main principle of this theory states that there is a working relationship between the party who gives the authority (principal), namely the shareholders, and the party who receives the authority (agent), namely the manager. Agency conflicts that result in opportunistic management characteristics that will result in pseudo-reported earnings, resulting in low earnings quality, which in turn reduces the value of the firm in the future. The low quality of earnings results in errors in decision making by users of financial statements such as investors and creditors, so that the company's value will decrease (Almadara, 2017).

Earnings management practices that are often carried out by management can reduce the quality of a company's financial statements, besides this action can harm investors because they will get inappropriate information about the company's financial position. It is considered to have become a serious problem faced by practitioners, accounting academics and finance in recent decades. To reduce the occurrence of earnings management actions, efforts that can be made include building a better supervision and control system, because this will encourage justice, transparency, accountability and responsibility in managing a company. This system can be done by implementing good corporate governance (Wardhani \& Joseph, 2010).

Earnings management behavior is always associated with negative behavior because earnings management causes the display of financial information not to reflect the actual situation. This occurs as a result of the asymmetric relationship between management, shareholders and other interested parties. To minimize the occurrence of earnings management actions, the company must choose a quality audit. Audit quality is selected from the role of auditors who have adequate competence and are independent so that they become parties who can provide assurance on the integrity of the accounting numbers reported by management (Utami, 2017). Numerous studies have found that the audit committee plays a truly important role in controlling earnings management. As proof, in the United States market (Khurnanto, 2015) it is found that exaggerated earnings reports are not likely to come from companies that have an audit committee. Baxter \& Cotter (2009) also note that the establishment of an audit committee reduces deliberate earnings management in a sample of Australian listed firms.

\section{Review of Literatures}

\subsection{Theory Agency (Agency Theory)}

Jensen and Meckling (1976) suggest that agency conflict occurs because of a disharmony between company owners and managers. This disharmony arises because of the differences in interests between managers and company owners, where one of them tries to maximize their own wealth. In addition, the information asymmetry possessed by the manager and owner of the company is also a cause of conflict between the two. It is the fact that managers hold superior information about the state of the company compared to company owners which ultimately triggers the classic agency conflict between company owners and managers.

Agency theory proposes that the monitoring mechanism is assumed to align the interests of managers and shareholders and to reduce conflicts of interest and any opportunistic behavior that results from it (Saleem \& Alzoubi, 2016). Shareholders assess a manager's performance based on his ability to generate company profits. Conversely, managers try to meet the demands of shareholders to generate maximum profits in order to get the desired compensation or incentives. However, managers often manipulate when 
reporting the condition of the company to shareholders so that the goal of getting compensation can be achieved (Almadara, 2017).

\subsection{Profit Management}

Quoting Schipper's opinion published in the book by Subramanyam \& John (2010), states that the definition of earnings management is as follows: "Earning management can be defined as the" purposeful intervention by management in the earning determination process, only to satisfy selfish objects ". The purpose of this definition is that earnings management can be defined as deliberate management intervention in the process of determining earnings, usually to meet personal goals. Often times this process involves beautifying the financial statements, especially the bottom number, namely profit. Earnings management can be cosmetic, if managers manipulate accruals that have no cash flow consequences. Profit managers can also be seen as real, if managers choose actions with cash flow consequences in order to change earnings.

From the above understanding it can be said that earnings management is a preparation of financial reports that is deliberately carried out by management which is shown to external parties by leveling, raising and lowering the earnings report with the aim of creating company performance so that it looks better than it actually is and to obtain some benefits. personal.

\subsection{Managerial Ownership}

According to Thanatawee (2014) managerial ownership, namely: "Shareholders who also mean in this case as owners in the company and owner managers actively participate in decision making in a company concerned". According to Safari, et al. (2018) managerial ownership is the shareholder of management who is active in making company decisions (directors and commissioners). Managerial ownership is share ownership by company management. Managerial share ownership can align the interests of shareholders and managers, because managers can directly benefit from the decisions taken and managers who bear the risk if there are losses that arise as a consequence of making wrong decisions. According to Jensen (1976), the greater the proportion of management ownership in the company will be able to unite the interests of managers and shareholders.

From some of the definitions above, managerial ownership is the owner of the company's shares which comes from management who participates in the decision making of a company concerned. Thus, ownership of shareholders by managers is expected to act in accordance with the wishes of the principals because managers will be motivated to improve performance. The size of the number of managerial shareholdings in the company indicates a common interest between managers and shareholders.

\subsection{Audit Quality}

DeAngelo (1981) defines audit quality as an assessment by the market where it is possible that the auditor will provide a) findings regarding a violation in the client's accounting system; and b) there is a violation in its recording. The likelihood that the auditor will report a misstatement has been detected and is defined as auditor independence. An auditor is required to be able to produce high quality work, because the auditor has a big responsibility for the parties who have an interest in the financial statements of a company, including the public. Audit quality can be interpreted as whether or not an audit has been carried out by the auditor. Based on the Public Accountant Professional Standards (SPAP) audits carried out by auditors are said to be of quality, if they meet the auditing requirements or standards. Auditing standards include professional quality, independent auditors, judgments used in conducting audits, and preparing audit reports (Kurniati, 2016). 
From some of the definitions above, audit quality is a characteristic or description of the practice of audit results based on auditing standards and quality control standards, which is a measure of the implementation of the duties and responsibilities of a professional auditor when auditing the client's financial statements and finding violations so that they can be reported in the audit financial report. where in carrying out these duties the auditors are guided by auditing standards and the relevant public accountant code of ethics.

\subsection{Audit Committee}

The audit committee is a body formed in a client company that has the task of maintaining the independence of the auditing accountants towards management (Siam et al, 2014). The audit committee is formed by the board of directors who have the task of carrying out independent oversight of external audits and the financial reporting process. Meanwhile, according to Anita (2016) the audit committee is a committee formed by the board of commissioners and is responsible to the board of commissioners to help carry out the duties and functions of the board of commissioners. Ghafran \& O'Sullivan (2017) states that the audit committee must consist of non-executive directors and have a minimum of three members, most of whom must be independent non-executives. It is further recommended that the audit committee meet no less than twice a year.

According to Zalata \& Roberts (2017) in their role as supervisors of the company's financial reporting process, members of the audit committee meet regularly with company managers and auditors to review the company's financial reports, the audit process and internal accounting controls. To increase the effectiveness of audit committees after accounting scandals, such as the Enron Scandal in the United States, there is now a requirement in many countries for some audit committee members to have financial expertise (Badolato et al, 2014; Committee, 2003). Based on some of the definitions above, the audit committee is a body formed by company management which has the task of helping to carry out duties and maintaining the independence of the accountants.

\section{Research Method}

\subsection{Types of Research and Data Sources}

This research uses quantitative research methods. The data in this study comes from secondary data, which comes from the financial statements of manufacturing companies in the consumer goods industry which were published on the Indonesia Stock Exchange in 2014-2018, which are included in the annual report, ICMD (Indonesian Capital Market Directory). IDX Statistics 2014-2018, website www.idx.co.id.

\subsection{Population and Sample}

The target calculation in this study is the financial statement data of manufacturing companies in the consumer goods industry sector which are listed on the Indonesia Stock Exchange, there are 42 companies. The sampling technique which is silent is purposive sampling. The selected samples are 10 manufacturing companies in the consumer goods industry which are listed on the Indonesia Stock Exchange and have certain criteria that support the research.

\subsection{Definition and Measurement of Variables \\ a. Dependent Variable}

Earnings management is the ability to manipulate the available choices and make the right choices to be able to achieve the desired profit level (Almadara, 2017). Earnings 
management (DAC) can be measured through discretionary accruals which are calculated by setting aside total accruals (TAC) and nondiscretionary accruals (NDA). The calculation model is as follows:

1) Total accruals using the modified Jones model.

- $\mathrm{TAC}=\mathrm{NI}_{\mathrm{it}}-\mathrm{CF}_{\mathrm{it}}$

- Where,

- $\mathrm{TAC}=$ Total accruals

- $\mathrm{NI}_{\mathrm{it}}=$ net income ( net income) company i period $\mathrm{t}$

- $\mathrm{CF}_{\mathrm{it}}=$ cash flow of operation of company $\mathrm{i}$ in period $\mathrm{t}$

2) The total accruals estimated by the OLS ( Ordinary Least Square ) regression equation are:

- $\mathrm{TAC}_{\mathrm{t}} / \mathrm{TA}_{\mathrm{t}-1}=(\beta)_{1}\left(1 / \mathrm{TA}_{\mathrm{t}-1}\right)+(\beta)_{2}\left(\Delta \mathrm{REV}_{\mathrm{t}} / \mathrm{TA}_{\mathrm{t}-1}\right)+(\beta)_{3}\left(\mathrm{PPE}_{\mathrm{t}} / \mathrm{TA}_{\mathrm{t}-1}\right)+\mathrm{e}$

- Where,

- TAC $_{\mathrm{t}} \quad=$ Total accruals in period $\mathrm{t}$

- $\mathrm{TA}_{\mathrm{t}-1} \quad=$ total assets period $\mathrm{t}-1$

- $(\Delta) \mathrm{REV}_{\mathrm{t}} \quad=$ Change in income in period $\mathrm{t}$

- PPE $_{\mathrm{t}} \quad=$ Property, plan and equipment period $\mathrm{t}$

- $\quad(\beta)_{1,}(\beta)_{2}(\beta)_{3}=$ Regression coefficient

- $\mathrm{e}=$ Error term (Error)

3) Discretionary Non Accruals

- NDTAC $_{\mathrm{t}}=(\beta)_{1}\left(1 / \mathrm{TA}_{\mathrm{t}-1}\right)+(\beta)_{2}\left[\left(\Delta \mathrm{REV}_{\mathrm{t}}-\Delta \mathrm{REC}_{\mathrm{t}}\right) / \mathrm{TA}_{\mathrm{t}-1}\right]+(\beta)_{3}\left(\mathrm{PPE}_{\mathrm{t}} / \mathrm{TA}_{\mathrm{t}-1}\right)+\mathrm{e}$ Where,

- NDTAC $_{\mathrm{t}}=$ Non discretionary accruals in year $\mathrm{t}$

- $\mathrm{TA}_{\mathrm{t}-1}=$ total assets period $\mathrm{t}-1$

- $(\Delta) \mathrm{REV}_{\mathrm{t}}=$ Change in income in period $\mathrm{t}$

- $(\Delta) \mathrm{REC}_{\mathrm{t}} \quad=$ Change in accounts receivable in period $\mathrm{t}$

- $\mathrm{PPE}_{\mathrm{t}} \quad=$ Property, plan and equipment period $\mathrm{t}$

- $(\beta)_{1,}(\beta)_{2},(\beta)_{3}=$ Fitted coefficient obtained from the regression results on the calculation of total accruals

- $\mathrm{e}=$ Error term (Error)

4) Total Accrual Discretionary

- DTAC $_{t}=\mathrm{TAC}_{\mathrm{t}} / \mathrm{TA}_{\mathrm{t}-1}-$ NDTAC $_{\mathrm{t}}$ Where,

- DTAC $_{\mathrm{t}}=$ Discretionary total accruals year $\mathrm{t}$

- $\mathrm{TAC}_{\mathrm{t}}=$ Total accruals in year $\mathrm{t}$

- $\mathrm{TA}_{\mathrm{t}-1}=$ total assets period $\mathrm{t}-1$

- NDTAC $_{\mathrm{t}}=$ Non discretionary accruals in year $\mathrm{t}$

\section{b. Independent Variable}

- Managerial ownership is the percentage of the number of shares owned by management who actively participates in company decision making (Permanasari, 2010).

$$
\mathrm{KM}=\frac{\text { the number of shares owned by commissioners and management }}{\text { the number of shares outstanding }} \times 100 \%
$$

- Audit quality can be interpreted as whether or not an audit has been carried out by the auditor. Based on the Public Accountant Professional Standards (SPAP) audits carried out by auditors are said to be of quality, if they meet the auditing requirements or standards. Auditing standards include professional quality, independent auditors, 
judgments used in conducting audits, and preparing audit reports (Kurniati, 2016). This variable is proxied by Auditor Size ( 1 if the company is audited by Big Four auditors, 0 otherwise) (Zgarni, et al., 2016).

- The audit committee is a committee formed by the board of commissioners to supervise the management of the company. The audit committee is measured by counting the number of audit committee members from each company used as the sample in this study. This variable is measured by how much the composition of the audit committee formed in issuers whose members come from outside the company divided by the total number of audit committee members (Al-Matari et al., 2014).

$$
\mathrm{KA}=\frac{\Sigma \mathrm{KAki}}{\Sigma K A} \times 100 \%
$$

Where:

KA : Audit Committee

$\Sigma$ KAki : The number of audit committees from independent commissioners

$\Sigma \mathrm{KA} \quad$ : Number of audit committee

\subsection{Data Analysis Method}

a. Classic Assumption Test

The classic assumption test is used to test whether the regression model really shows a significant and representative relationship. The data used are secondary data, so to determine the accuracy of the model it is necessary to test several class assumptions that underlie the regression model, namely the data normality test, multicollinearity test, heterocedasticity test, and autocorrelation test.

\section{b. Multiple Linear Regression Analysis}

Regression analysis is used to measure the strength of the relationship between two or more variables, it also shows the direction of the relationship between the dependent and independent variables. The objective of multiple linear regression analysis is to use the values of known variables to predict the value of the dependent variable. The formulation of the multiple linear regression equation is as follows:

$$
\mathrm{Y}=\mathrm{a}+\mathrm{b} 1 \mathrm{X} 1+\mathrm{b} 2 \mathrm{X} 2+\mathrm{b} 3 \mathrm{X} 3+\mathrm{e}
$$

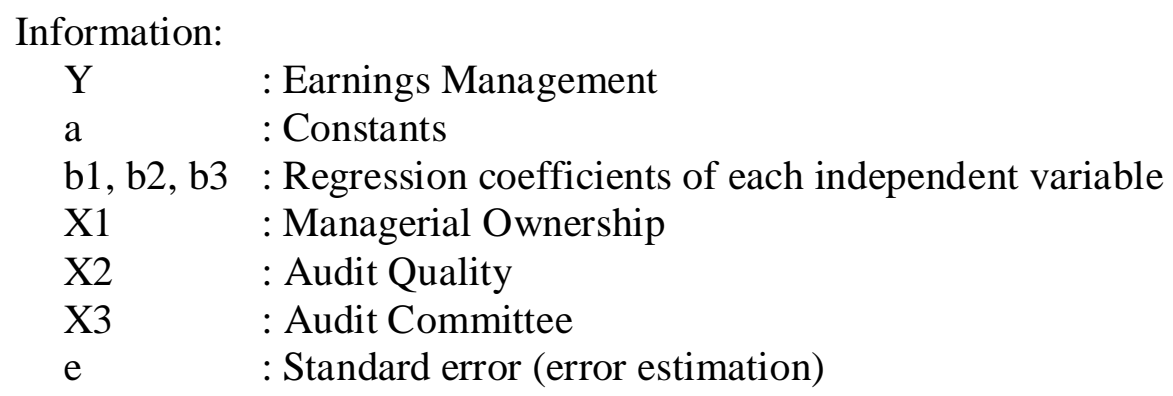




\section{Discussion}

\subsection{Classical Assumption Test and Multiple Linear Regression Analysis}

Table 1. Classic Assumption Test

\begin{tabular}{|c|c|c|c|c|c|c|}
\hline \multirow[t]{2}{*}{ Parameters tested } & \multicolumn{2}{|c|}{ Normality test } & \multicolumn{2}{|c|}{$\begin{array}{c}\text { Multicollinearity } \\
\text { Test }\end{array}$} & \multirow{2}{*}{$\begin{array}{c}\text { Heteroscedasticity } \\
\text { Test }\end{array}$} & \multirow{2}{*}{$\begin{array}{c}\begin{array}{c}\text { Autocorrela } \\
\text { tion Test }\end{array} \\
\text { DW }\end{array}$} \\
\hline & $\mathrm{Z}$ & $\mathrm{P}$ & Tolerance & VIF & & \\
\hline $\begin{array}{l}\text { Unstandardized } \\
\text { Residual }\end{array}$ & 0.749 & 0.629 & & & & \\
\hline KM & & & 0,947 & 1,056 & 0,345 & \\
\hline KUA & & & 0,942 & 1,062 & 0,209 & \\
\hline KOA & & & 0,977 & 1,024 & 0,518 & \\
\hline Durbin-Watson & & & & & & 1,558 \\
\hline
\end{tabular}

Table 2. Analysis Result of Multiple Linear Regression

\begin{tabular}{lllccc}
\hline \multicolumn{1}{c}{ Variable } & $\begin{array}{l}\text { Regression } \\
\text { Coefficient }\end{array}$ & $\mathrm{t}$ & Sig. & F count & Sig. F \\
\hline 1 (Constant) & & $-9,874$ & 0,000 & & \\
KM & 0.020 & 0.152 & 0.880 & \multirow{2}{*}{5,220} & 0.003 \\
KUA & 0.298 & 2,274 & 0.028 & & \\
KOA & 0.373 & 2,894 & 0.006 & & \\
\hline
\end{tabular}

The results of testing the classical assumptions in Table 1 show that this study is free from problems of normality $(0.629>0.05)$, multicollinearity (Tolerance value variable KM $0.947>0.10$ and VIF $1.056<10$, KUA $0.942>0.10$ and VIF $1.062,<10$, KOA 0.977> 0.10 and VIF Value $1.024<10$ ), heteroscedasticity (KM 0.345, KUA 0.209, and KOA 0.518> $0.05)$ and autocorrelation $(1<1.558<3)$, so that the test model was free from problems. Classic assumption testing.

Table 2 shows the calculated $F$ value of 5.220 with a significance level of 0.003 and the F count of 5.220> F table 2, 81 or the Sig.F value of $0.003<0.05$. This means that managerial ownership, audit quality and audit committee simultaneously affect earnings management.

\subsection{Discussion of Research Results}

\section{a. The Effect of Managerial Ownership on Earnings Management}

From the results of table 2 it can be seen that the managerial ownership variable with a significance value of $0.880>0.05$. This shows that managerial ownership has no effect on earnings management. Thus, the hypothesis which states that managerial ownership has a significant effect on earnings management is rejected. These results prove that managerial ownership is not proven to be able to be used as a means of reducing agency cost between owners and management. The results of this study do not prove the agency theory which explains that managerial ownership can reduce agency problems that occur between management and shareholders. Share ownership by managers in the company will be able to create optimal company performance and motivate managers to act to be more careful, because they share the consequences of every action they take.

This is not in line with the results of research conducted by O'Callaghan et al., (2018); Midiastuty and Machfoedz (2003); Warfield et al., (1995) and Gabrielsen et al., (2002) concluded that managerial ownership has a negative effect on earnings management 
as proxied by discretionary accruals. Increasing managerial ownership will align or unite the interests of managers and shareholders, thereby reducing opportunistic behavior. $\mathrm{D}$ ith their managerial ownership in the company will decrease the action of earnings management because managers will help create the company's performance optimally, be vigilant and cautious in making decisions, also benefit from the decision and bear the loss of some consequences of making the wrong decision. Large share ownership in terms of economic value has an incentive to monitor it. Management's ownership of company shares is seen as being able to align the potential differences between the interests of outside shareholders and management.

\section{b. Effect of Audit Quality on Earnings Management}

From the results of table 2 it can be seen that the variable with a significance value of $0.028<0.05$. This shows that audit quality has an influence on earnings management. Thus, the hypothesis which states that audit quality has a significant effect on earnings management is accepted. This is because companies audited by large accounting firms are proven to limit earnings management behavior by the company and do not increase earnings management actions. The results of the study are in line with the theory that one way to monitor earnings management practices is to audit financial statements. It is assumed that a quality audit is influenced by a qualified auditor (Zgarni et al, 2016). Audit quality is proven to be able to reduce earnings management practices that occur in the company. KAP with a good reputation will of course maintain its good name by carrying out a good and effective audit process. Investors will also assume that the financial statements audited by the big four KAP can be more reliable than those audited by other than the big four. The quality of external audits is actually able to reduce earnings management practices in the company.

The results of this study are in line with the results of research by Sudjatna \& Muid (2015); Gerayli et al., (2011); Rusmin (2010) which shows that audit quality has a significant effect on earnings management as measured by discretionary accruals. Alhadab \& Clacher (2017) show that the larger the audit firm size, the lower the amount of earnings management. Ching, et al., (2015) also show that the big four is able to prevent and reduce earnings management while maintaining its reputation as measured by absolute discretionary accruals. However, the results of this study are not in line with research conducted by Christiani (2014); Sunandar, et al (2014) and Indriastuti (2012), which in their research stated that audit quality does not have a significant effect on earnings management. But this is because the companies that were the sample in this study were only a small part of which used Big-4 auditors and mostly used non-Big-4 auditors.

\section{c. The Effect of the Audit Committee on Earnings Management}

From the results of table 2 it can be seen that the variable with a significance value of $0.006<0.05$. This shows that the audit committee has an influence on earnings management. Thus, the hypothesis which states that the audit committee has a significant effect on earnings management is accepted. This means that the audit committee variable which is measured based on the percentage of the members of the audit committee can reduce earnings management carried out by the management in a company. The results of this study are in line with agency theory which states that a high audit committee size creates a more supervisory function for the company so that it can reduce problems at the company such as earnings management practices. The role of the audit committee reflects the principles of agency theory and the need to monitor management to ensure that it uses company resources in the best interests of shareholders (Bilal, et al., 2018). Based on agency theory, to reduce earnings management actions in the company, investors make agent fees in monitoring 
management actions in the company (Sugiarti, 2015). This is in line with the results of research conducted by Inaam \& Khamoussi (2016); Pamuji (2010); Juhmani (2017), found a relationship between the audit committee and earnings management. The expectation that the audit committee has more advanced accounting and financial knowledge. They have better understanding and oversight of the financial reporting process and are more effective at monitoring and limiting management's activities to manipulate earnings.

Previous research is in line with this research conducted by Marsha \& Ghozali (2017); Salihi \& Jibril (2015) state that there is an influence between the size of the audit committee on earnings management. This proves, the greater the number of audit committee personnel, the better the supervisory process carried out by the audit committee so that the less chance the company has to perform earnings management. The results of this study reinforce the statements of Mishra \& Malhotra (2016) and Juhmani (2017) which state that an audit committee with a larger number of members allows them to exchange different expertise and experiences so that the supervisory process becomes more effective which in turn causes the company to be able to produce good quality earnings information.

\section{d. The Effect of Managerial Ownership, Audit Quality, and Audit Committee on Earnings Management}

The significance level of testing obtained from this regression is 0.003 . Then the calculated $\mathrm{f}$ value for the regression of managerial ownership, audit quality, and audit committee variables on earnings management simultaneously obtained 5.220 which when compared with the $f$ table value of 2.81 , the calculated $f$ value is greater than $f$ table. This concludes that managerial ownership, audit quality, and audit committee simultaneously have a significant effect on earnings management.

Furthermore, the coefficient of determination ( $\mathrm{R}$ Square) obtained is 0.254 . This value is then multiplied by $100 \%$ so that it shows the contribution or contribution of the influence of the three variables of managerial ownership, audit quality, and audit committee on earnings management of $25.4 \%$, while the remaining $74.6 \%$ is the contribution of other variables not included in this study.

\section{Conclusion}

\subsection{Conclusion}

First, the results of testing the hypothesis about the effect of managerial ownership on earnings management can be seen that the t-count on the managerial ownership variable is smaller than the t-table $(<)$ and the regression coefficient value is 0.020 with a significance of 0.880 , so it can be concluded that managerial ownership is not has a significant effect on earnings management in consumer goods manufacturing companies listed on the Indonesia Stock Exchange.

Second, the results of hypothesis testing about the effect of audit quality on earnings management can be seen that the t-count on the audit quality variable is greater than the $\mathrm{t}$ table (>), and shows that the regression coefficient value is 0.298 with a significance of 0.028 , so it can be concluded that the audit quality influence on earnings management in consumer goods manufacturing companies listed on the Indonesia Stock Exchange.

Third, the results of hypothesis testing about the effect of the audit committee on earnings management can be seen that the t-count on the audit committee variable is greater than the t-table (>), and the regression coefficient value is 0.373 with a significance of 0.006 , so it can be concluded that the audit committee has an effect on earnings management in consumer goods manufacturing companies listed on the Indonesia Stock Exchange. 


\subsection{Suggestion}

\section{a. For the Company}

With the influence of managerial ownership, audit quality, and audit committee on earnings management, this can be a recommendation for each company to maintain or improve the quality of managerial ownership regulations, audit quality, and audit committees in their management system in order to improve the quality of earnings management.

\section{b. For Further Researchers}

In future studies, you should increase the number of samples in the study and extend the research period not only to five years. A longer period of research can better reflect the true condition. Future researchers are expected not only to use the four research variables, but also to add other variables that are not examined in this study.

\section{References}

Alhadab, Mohammad. Clacher, Iain. (2017). The Impact of Audit Quality on Real and Accrual Earnings Management around Ipos. The British Accounting Review.

Al-Matari, E.M., Al Swidi, A.K., and Fadzil, F.H.B. (2014). The Effect of Board of Directors Characteristics, Audit Committee Characteristics and Executive Committee Characteristics on Firm Performance in Oman: An Empirical Study. Asian Social Science. 10(11). pp. 149-171.

Almadara, Hafidza Ulfa. (2017). Pengaruh Leverage terhadap Manajamen Laba dengan Corporate Governance sebagai Variabel Moderasi pada Perusahaan Perbankan yang Terdaftar di BEl. Skripsi. Yogyakarta.

Anindyah, Prastiti. (2013). Pengaruh Karakteristik Dewan Komisaris dan Komite Audit terhadap Manajemen Laba. Jurnal Universitas Dipenogoro. Vol.2 No.4.

Anita, Aprilia. Yulianto, Arief. (2016). Pengaruh Kepemilikan Manajerial dan Kebijakan Dividen terhadap Nilai Perusahaan. Management Analysis Journal 5(1).

Badolato, P.G. Donelson, D.C. Ege, M. (2014). Audit Committee Financial Expertise And Earnings Management: The Role Of Status. Journal of Accounting and Economics, 58. 208-230.

Baxter, Peter. Cotter, Julie. (2009). Audit Committees and Earnings Quality. School of Accounting, Economics and Finance. Faculty of Business University of Southern Queensland, Toowoomba.

Bilal. Chen, Songsheng. Komal, Bushra. (2018). Audit Committee Financial Expertise and Earnings Quality: A Metaanalysis. Journal of Business Research 84 253-270

Chaudhry, G., and Noel, O. (2017). The Impact Of Audit Committee Expertise On Audit Quality: Evidence From Uk Audit Fees. The British Accounting Review 49 578593.Chi, H-Y., Weng, T-C. (2014). Managerial Legal Liability and Big 4 Auditor Choice. Journal Of Business Research 67 (9): 1857-18.

Ching, C.P. Teh, B.H. San, O.T. Hoe, H.Y. (2015). The Relationship Among Audit Quality, Earnings Management, and Financial Performance of Malaysian Public Listed Companies. International Journal of Economics \& Management. Vol. 9, No. 1, Pp. 211229. 
Christiani, Inggrid. Nugrahanti, Y. Widi. (2014). Pengaruh Kualitas Audit terhadap Manajemen Laba. Jurnal Akuntansi dan Keuangan. Vol. 16 No.1

Commitee, Smith. (2003). Audit Committees, Combined Code Guidance. A Report and Proposed Guidance By The Frc - Appointed Group. London: Frc.

DeAngelo, Linda Elizabeth. 1981. Auditor Size and Audit Quality. Journal of Accounting and Economics (3): 183-199.

Felicia, M., and Imam, G. (2017). Pengaruh Ukuran Komite Audit, Audit Eksternal, Jumlah Rapat Komite Audit, Jumlah Rapat Dewan Komisaris dan Kepemilikan Institusional terhadap Manajemen Laba. Diponegoro Journal of Economics. Vol. 6, Hal 1-12.

Gabrielsen, G. Gramlich, J.D. Plenborg, T. (2002). Managerial Ownership, Information Content of Earnings and Discretionary Accruals in aNon-US Setting. Journal of Business Finance and Accounting, 29. (7). 967-988.

Gerayli, M. Ma'atofa, S. Yane, S.A.M. (2011). Impact of Audit Quality on Earning Management: From Iran. Internasional Research Journal of Finance and Economics. Vol. 66, Pp. 77-84.

Inaam, Z., and Khamoussi, H. (2016). Audit Committee Effectiveness, Audit Quality And Earnings Management: A Meta-Analysis. International Journal Of Law And Management, 58(2), 179-196.

Indriastuti, Maya. 2012. Analisis Kualitas Auditor dan Corporate Governance terhadap Manajemen Laba. Eksistansi. Vol. 4 No. 2.

Isnaini, Zulyadi, R., and Kadir, A. (2020). The Models of North Sumatra Provincial Government Policy in Resolving the Ex-Hgu Land Conflicts of PTPN II Plantations in Deli Serdang Regency. Budapest International Research and Critics Institute-Journal (BIRCI-Journal) Vol 3 (2): 1206-1215.

Jensen, Meckling, M.C., and William, H. (1976). Theory of The Firm: Managerial Behavior, Agency Costs and Ownership Structure. Journal of Financial Economics 3. Hlm. 305360.

Juhmani, O. (2017). Audit Committee Characteristics and Earnings Management: The Case of Bahrain. International Journal of Accounting and Financial Reporting. Vol.7 No.1 Pp.11-28

Khurnanto, and Farras, R. (2015). Pengaruh Komite Audit dan Audit Eksternal terhadap Manajemen Laba. Skripsi. Semarang: Fakultas Ekonomi dan Bisnis Universitas Diponegoro.

Kurniati, Herni. (2016). Pengaruh Board Size, Leverage, dan Kualitas Audit terhadap Nilai Perusahaan. Jurnal Keuangan dan Perbankan, Vol. 12, No.2.

Midiastuty, P.P., and Mahfoedz, M. (2003). Analisis Hubungan Mekanisme Corporate Governance dan Indikasi Manajemen Laba. Seminar Nasional Akuntansi VI. 176-199.

Mishra, M., and Malhotra, A.K. (2016). Audit Committee Characteristics and Earnings Management: Evidence From India. International Journal of Accounting and Financial Reporting. Vol.6 No.2 Pp.247-271.

Permanasari, and Ika, W. (2010). Pengaruh Kepemilikan Manajemen, Kepemilikan Institusional dan Corporate Social Responsibility terhadap Nilai Perusahaan. Skripsi. Semarang: Fakultas Ekonomi Universitas Diponegoro. 
Rusmin. (2010). Auditor Quality and Earnings Management: Singaporean Evidence. Managerial Auditing Journal. Vol. 25, Pp. 618-638.

Safari, R.K., Suzan, L., and Aminah, W. (2018). Effect of Managerial Ownership, Institutional Ownership and Assets Intangible Assessment to The Firm Value. EProceeding of Management. Vol.5, No.1. ISSN: 2355-9357.

Saleem, E., and Alzoubi, S. (2016). Audit Quality And Earnings Management: Evidence From Jordan. Journal Of Applied Accounting Research. Vol. 17 Iss 2 Pp.

Salihi, A.A. Jibril, R.S. (2015). The Effect of Board The Size and Audit Committee the Size on Earnings Mangement in Nigerian Consumer Industries Companies. International Journal of Innovative Research and Development. Vol.4 No.3 Pp.84-91.

Scott, and William, R. (2014). Financial Accounting Theory. Seventh Edition. Canada Prentice Hall, 403.

Siam, Y.I.S.A., Laili, N.H.B., Khairi, K.F.B., and Jebreel, M.F. (2014). Audit Committee Characteristics, External Audit and Earnings Management Among Jordanian Listed Companies: Proposing Conceptual Framework. Proceedings of the Australian Academy of Business and Social Sciences Conferences 2004 (In Partnership with The Journal of Developing Areas).

Shah, M.M., Sirojuzilam, and Mass, L.T. (2020). The Development Impact of PT. Medco E \& P Malaka on Economic Aspects in East Aceh Regency. Budapest International Research and Critics Institute-Journal (BIRCI-Journal) Vol 3 (1): 276-286.

Steve, O., John, A., and Lynn, H. (2018). Earnings Management and Managerial Ownership in Private Firms. Journal of Applied Accounting Reseacrh.

Sudjatna, Indiferent. Muid, Dul. 2015. Pengaruh Struktur Kepemilikan, Keaktifan Komite Audit, dan Kualitas Audit terhadap Manajemen Laba. Diponegoro Journal of Accounting. Vol. 4, No. 4

Sugeng, P., and Aprilla, T. (2010). Pengaruh Independensi dan Efektivitas Komite Audit Terhadap Manajemen Laba. Universitas Dipenogoro Semarang. IndonesiaSubramanyam, K.R., John, and J, Wild. (2010). Analisis Laporan Keuangan. Buku Satu, Edisi Sepuluh. Jakarta: Salemba Empat.

Sugiarti, Ika. (2015). Pengaruh Kualitas Audit terhadap Manajemen Laba (Studi pada Perusahaan Perbankan di Bursa Efek Indonesia Tahun 2012-2014). E-Journal Ekonomi Bisnis dan Akuntansi

Sunandar, Farida, Ida. Alfin, M. (2014). Pengaruh Kualitas Audit dan Ukuran Komite Audit terhadap Manajemen Laba. Jurnal Bisnis dan Manajemen. Vol. 2 No. 2 Hal. 132-143

Thanatawee, Yordying. (2014). Institutional Ownership and Firm Value in Thailand. Asian Journal of Business and Accounting. 7(2). Pp. 1-22

Ugwunta, D.O., Ugwuanyi, B.U., and Ngwa, C.U. (2018). Effect of Audit Quality on Market Price of Firms Listed on the Nigerian Stock Market. Journal of Accounting and Taxation. Vol. 10 (6). Pp. 61-70.

Utami, Ajeng Elka Putri. (2017). Pengaruh Manajemen Laba terhadap Nilai Perusahaan dengan Kualitas Audit sebagai Variabel Pemoderasi. Skripsi. Bandung.

Wardhani, Ratna. Joseph, Herunata. (2010). Karakteristik Pribadi Komite Audit dan Praktik Manajemen Laba. Simposium Nasional Akuntansi XIII 
Warfield, T.D. Wild, J.J. Wild, J.K. (1995). Managerial Ownership Accounting Choices and Informativeness of Earnings. Journal of Accounting and Economics. Vol.20 (1). Pp.61 91.

Zalata, Alaa Mansour. Roberts, Clare. (2017). Managing Earnings Using Classification Shifting: UK Evidence. Journal of International Accounting, Auditing and Taxation. Vol. 29. Hlm: 52-65.

Zgarni, Inaam. Hlioui, Khmoussi. Zehri, Fatma. (2016). Audit Committee's Effectiveness, Audit Quality and Earnings Management: Evidence from Tunisia. Journal of Accounting In Emerging Economies, Vol. 6 (2). 